\title{
Utilization of Pretreated Lignocelluloses Materials for the Production of Bio-Diesel
}

\author{
S. Arasaretnam*, JMPW. Jayasundara \\ Department of Chemistry, Faculty of Science, Eastern University, Sri Lanka
}

*Corresponding Author: S. Arasaretnam, Department of Chemistry, Faculty of Science, Eastern University, Sri Lanka

\begin{abstract}
The formation of ethanol from food such as corn, sugarcane etc. is a popular method of making ethanol. This study explains using renewable feed for the production of ethanol from cellulose. Rice husk and water hyacinth were used to carry out the experiment for the manufacture of ethanol. The powdered rice husk and water hyacinth were exposed to physical pretreatment and chemical pretreatment prior to enzymatic and hydrolysis process. Physical pretreatments and chemical pretreatment (acid pretreatment) were used to enhance the conditions for maximum ethanol yield from rice husk and water hyacinth. As a result of qualitative test, pretreatment methods had been useful on rice husk and water hyacinth in order to upsurge the available cellulose amount and also improve the enzymatic hydrolysis efficiency. The FTIR study revealed that characterization of pretreated rice husk and water hyacinth and suggests that both samples contain a substantial amount of ethanol. Pretreatment aided the highest sugar yield from enzymatic hydrolysis of pretreated rice husk and water hyacinth. Hence pretreated rice husk and water hyacinth could be useful as a carbon source for subsequent bio-ethanol production.
\end{abstract}

Keywords: ethanol, renewable feed, cellulose, pretreatment, and qualitative

\section{INTRODUCTION}

Energy has become as one of the most important strategic commodities considered to be the lifeline of an economy and it is pivotal for human existence ${ }^{1,2,3}$. Today the world is facing a serious energy crisis all over the world due to development in industrialization and motorization and population explosion as well. Because of that there is need to find out the alternative techniques and today fossil fuels take up $80 \%$ of the primary energy consumed in the world, of which $58 \%$ alone is consumed by the transport sector. Energy reform is well underway around the world due to two primary factors, namely, the impact of fossil fuels on the environment and the predicted supply fallout of such nonrenewable fuels in the long term ${ }^{4,5}$.

Bio-ethanol is the cleanest liquid fuel and biodegradable, environmental friendly fuel. It has higher octane number and higher heat vaporization and produces fewer emission of carbon dioxide $\left(\mathrm{CO}_{2}\right)$ and carbon monoxide (CO) when replacing gasoline in modified engine ${ }^{4,6}$. And also it is an excellent fuel for today flex-fueled vehicles ${ }^{7}$.

Currently, saccharides based material, such as sugarcane or sugar beet and starch based material such as corn and wheat are especially used in bio-ethanol industry ${ }^{3}$. The growing demand of bio-ethanol fuel has emerged to the increasing the demand of agricultural land and consequently growing demand for food ${ }^{5}$. Compared with bio-ethanol produces from food crop, lignocellulose biomass convert into bio-ethanol is the most advanced biofuel production technology in today because of its abundance and low $\operatorname{cost}^{8}$.

Sri Lanka is an agricultural country and the rice which is the primary food in Sri Lanka. Rice husk is used as thermal energy source in some industrial and domestic, animal feed and dumped and in recent Sri Lank forces on power generation using rice husk ${ }^{9}$. Rice husk contains nearly $36 \%$ of cellulose, 12 $\%$ of hemicellulose and $16 \%$ of lignin. Therefore it is a potential excellent source for production of bio-ethanol ${ }^{10}$. 
Eichhornia crassipes is referred as water hyacinth which is belongs to family of pontederiaceae ${ }^{11}$. Water hyacinth which is believed to have been introduced to Sri Lanka as an ornamental plant has become a serious pest in waterway, ponds, and slow running stream in the coastal districts of North Western, Western and the Southern Provinces ${ }^{12}$. It grows over a wide variety of wetland types from lakes, streams, ponds, waterways, ditches, and backwater areas that has proven to be an economic and ecological problem ${ }^{13,14}$. Water hyacinth contains cellulose (20-25\%), hemicellulose (20-35\%), and polyphenolic lignin (10-35\%) ${ }^{15}$.

Therefore present study was intended to focus on review of lignocellulosic feedstock of rice husk and water hyacinth convert them into ethanol fuel which is very important economically.

\section{MeTHOdOLOGY}

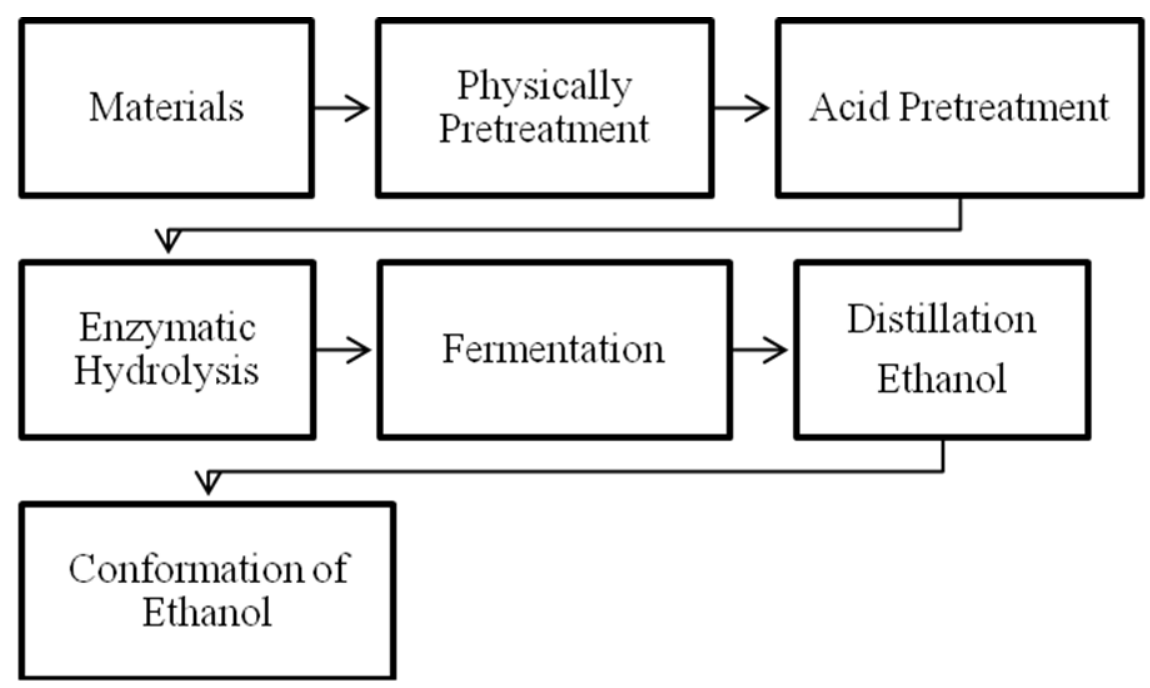

Figure1. Simplified flowchart of methodology

\subsection{Collection of Lignocellulosic Materials}

Rice husks were collected from a rice mill at Polgahawela (Kurunegala, Sri Lanka) and Water hyacinths were collected from wet land in Batticaloa (Sri Lanka).

\subsection{Enzymes}

The cellulase and pectinase enzymes used in this study were commercial products of Ecochem (Pvt) Ltd (Sri Lanka).

\subsection{Yeast}

Yeast (Saccharomyces cerevisiae) used in this study was commercial products of AB Mauri Middle East Pty LTD (Sri Lanka).

\subsection{Physical Pretreatments}

The collected lignocellulosic materials (rice husk and water hyacinth) were washed with water to remove all the soluble impurities in the materials and repeated step until the wash water was clear prior to pretreatment. The washed materials were air-dried, cut (water hyacinths), oven dried for 6 hours at $60{ }^{\circ} \mathrm{C}$ and blended. Finely powdered samples were stored inside container at room temperature.

\subsection{Chemical Pretreatment (Acid Pretreatment)}

$20 \mathrm{~g}$ of each physically treated lignocelluloses substrates such as rice husks and water hyacinth were weighted and transferred into respective $250 \mathrm{ml}$ conical flasks. Each conical flask sample was soaked by $100 \mathrm{ml}$ of prepared $1 \mathrm{M} \mathrm{H}_{2} \mathrm{SO}_{4}$ for 24 hours and shaken $(150 \mathrm{rpm})$ at room temperature $\left(30 \pm 1^{\circ} \mathrm{C}\right)$. Each sample solid was recovered by filtration and washed repeatedly with distilled water until the water turn to $\mathrm{pH} 7.0$ for neutralization purpose. Subsequently each sample was dried at $80{ }^{\circ} \mathrm{C}$ to be constant weight in oven. 


\subsection{Enzymatic Hydrolysis}

$100 \mathrm{ml}$ of prepared $0.2 \mathrm{M}$ sodium acetates buffer at $\mathrm{pH} 5.0$ was added into the pretreated each sample and the $\mathrm{pH}$ value of each sample was adjusted at 5.0. Subsequently each sample was treated by adding $50 \mathrm{ml}$ of cellulose and pectinase enzymes. The each sample was shaken $(150 \mathrm{rpm})$ at $50{ }^{\circ} \mathrm{C}$ for 2 hours.

\subsection{Fermentation Process}

The $\mathrm{pH}$ value of enzymatic hydrolyzed each solution was adjusted to 5.5. Then samples were autoclaved at $121{ }^{\circ} \mathrm{C}$ for 15 minutes. After autoclaving, $5 \mathrm{~g}$ of yeast (Saccharomyces cerevisiae) was introduced into each sample. Then each sample was shaken $(100 \mathrm{rpm})$ for 7 hours and kept for 72 hours at room temperature $\left(30 \pm 1^{\circ} \mathrm{C}\right)$.

\subsection{Distillation}

Recovery of ethanol from crude fermentation broth of each sample was accomplished by using simple distillation process by setting the temperature of heating at $78^{\circ} \mathrm{C}$.

\subsection{Analytical Method}

\subsubsection{Qualitative Analysis}

The enzymatic hydrolyzed samples and distilled samples were subjected to several qualitative tests as follow for monomer sugar and ethanol, employing various chemicals.

Fehling's Test: An aqueous solution of enzymatic hydrolyzed sample $(2.0 \mathrm{ml})$ was taken in a test tube. Then Fehling's solution A (1.0 ml) (aqueous solution of $\left.\mathrm{CuSO}_{4}\right)$ add Fehling solution B $(1.0 \mathrm{ml})$ (solution of potassium tartrate) were added and mixed well and boiled. The changes were observed.

Benedict's test: An aqueous solution of enzymatic hydrolyzed sample $(2.0 \mathrm{ml})$ was taken in a test tube. Next Benedict's reagent $(5.0 \mathrm{ml})$ was added and added 8 drops of $\mathrm{NH}_{4} \mathrm{OH}$ to it. The test tube was placed in boiling water bath for 5 minutes and kept to cool. The changes were observed.

Iodoform test: 3 drops of an aqueous solution of distilled sample was taken in a test tube. Next $10 \%$ $\mathrm{NaOH}(1.0 \mathrm{ml})$ was added. Then iodine $\left(\mathrm{I}_{2}\right)$ solution was added drop wise with shaking and solution was warmed in water bath $\left(60^{\circ} \mathrm{C}\right)$ for 3 minutes with shaking from time to time. The changes were observed.

\subsubsection{FTIR Analysis}

An FTIR analysis was carried out one sample at Industrial Technology Institute (ITI), Colombo, Sri Lanka. FTIR spectrums were obtained using BRUKER TENSOR 27 Fourier Transform Infrared spectrometer.

\section{RESULTS AND DISCUSSION}

Table3.1. Qualitative tests and their respective observation of enzymatic hydrolyzed samples

\begin{tabular}{|l|l|l|}
\hline \multirow{2}{*}{\multicolumn{1}{|c|}{ Type of test }} & Observation of enzymatic hydrolyzed samples \\
\cline { 2 - 3 } & \multicolumn{1}{|c|}{ Rice husk } & \multicolumn{1}{c|}{ Water hyacinth } \\
\hline Fehling's Test & Yellowish red precipitate & Red precipitate \\
\hline Benedict's Test & Orange precipitate & Red precipitate \\
\hline
\end{tabular}

A positive result of Fehling's Test and Benedict's test would be indicated by a red precipitate in the test tube. Samples that tested positive to Fehling's Test and Benedict's test each rice husk and water hyacinth. In the cases of aldehyde group was important for the reaction to happen - they took part in the mechanism for the reaction. That led to a higher susceptibility to oxidation reactions, potential agents capable of reducing $\mathrm{Cu}^{2+}$ to $\mathrm{Cu}^{+}$.

Table3.2. Qualitative tests and their respective observation of distilled samples

\begin{tabular}{|l|l|}
\hline Distilled bio-ethanol Samples & Observation \\
\hline Rice Husk & Yellow Precipitate \\
\hline Water hyacinth & Yellow Precipitate \\
\hline
\end{tabular}


Iodoform test is specific for only one class of alcohol. This is the secondary methyl alcohol. If the alcohol contains a methyl group attached to a carbon that also has hydrogen and an $\mathrm{OH}$ group then it will give a positive iodoform test. The formation of a yellow precipitate indicates a positive test.

Table3.3. Observation of Specific gravity

\begin{tabular}{|l|l|}
\hline Distilled bio-ethanol Samples & Specific gravity \\
\hline Rice Husk & 0.7914 \\
\hline Water hyacinth & 0.7908 \\
\hline
\end{tabular}

The FTIR spectra of rice husks (RH) and water hyacinth (WH) samples showed that the Rice husks $(\mathrm{RH})$ and water hyacinth (WH) samples were dominated by the peaks at $3283 \mathrm{~cm}^{-1}$ and $3284 \mathrm{~cm}^{-1}$ respectively that are very broad and strong bands of the O-H stretch. The peaks at $2980 \mathrm{~cm}^{-1}$ and 2979 $\mathrm{cm}^{-1}$ were indicative of band of C-H stretch. The peaks observed at $1085 \mathrm{~cm}^{-1}$ and $1044 \mathrm{~cm}^{-1}$ and also peaks observed at $1085 \mathrm{~cm}^{-1}$ and $1044 \mathrm{~cm}^{-1}$ that correspond to the band of $\mathrm{C}-\mathrm{O}$ stretches. (Figure 2.0 and Figure 3.0, Appendex.1.0)

\section{CONClusion}

All the pretreatments carried out in this study, enzymatic hydrolysis of pretreated rice husk and water hyacinth promoted the highest yield of reducing sugar. The delignification effect of pretreatment had contributed in enhancing cellulose digestibility and overall ethanol productivity in the simultaneous saccharification and fermentation process (SSF). Response physical pretreatments and chemical pretreatment (acid pretreatment) methodologies were useful methods to optimize the conditions for maximum ethanol productivity from rice husk and water hyacinth.

Based on the results of current study, pretreated rice husk and water hyacinth can be considered as potential feedstock for bio-ethanol production especially in Sri Lanka where it is available in large quantity and relatively inexpensive.

\section{REFERENCES}

[1] Peter Zuurbier and Jos van de Vooren. (2008). Introduction to sugarcane ethanol contributions to climate change mitigation and the environment. Sugarcane ethanol, 19.

[2] Nyachaka, C. J., D. S. Yawas., and G. Y. Pam. (2013). Bio-Ethanol Production from Rice Husk and Performance Test of Petrol and Bio-ethanol Blends in a Spark Ignition Engine. International Journal of Engineering Research and Technology, 2. ESRSA Publications.

[3] Pooja, H., Rashmi A., Sabeena K., Abhijit Bhatkal., and Sastry, D. N. (2016). Production of Ethanol from Waste Newspaper. International Conference on Global Trends in Engineering, Technology and Management (ICGTETM).

[4] Bibi Z., and Fakhra A. (2014). Production of Ethanol by fermentation process by using Yeast Saccharomyces cerevisae. International Research Journal of Environment Sciences, 3(7):24-32

[5] Abbas, Ali., and Santosh Ansumali. (2010). Global potential of rice husk as a renewable feedstock for ethanol biofuel production. BioEnergy Research, 3(4):328-34.

[6] Mojovic, L., Nikolic, S., Pejin, D., Pejin, J., Djukic-Vukovic , A., Kocic-Tanackov, S., emencenko, V. (2013). The potential for sustainable bioethanol production in Serbia: available biomass and new production approaches, Materials and processes for energy: communicating current research and technological developments (A. Mendez-Vilas, Ed.) 380-392, CFORMATEX 2013.

[7] Renewable Fuels Association. Pocket Guide to ethanol 2015. (2015).

[8] Lin, Y., and Tanaka, S. (2006). Ethanol fermentation from biomass resources: current state and prospects. Applied microbiology and biotechnology, 69(6):627-42.

[9] Rodrigo, A., and Perera, S. (2013). Potential and Viability of Rice Husk Based Power Generation in Sri Lanka. Engineer: Journal of the Institution of Engineers, Sri Lanka, 46(4).

[10] Saha, B. C., Iten, L. B., Cotta, M. A., and Wu, Y. V. (2005). Dilute acid pretreatment, enzymatic saccharification, and fermentation of rice hulls to ethanol. Biotechnology Progress, 21(3): 816-822.

[11] Charudattan, R., Labrada, R., Center, T. D., and Kelly-Begazo, C. (1996). Strategies for water hyacinth control. Report of a Panel of experts meeting, 11-14 September, 1995, Fort Lauderdale, Florida, USA.

[12] Hettiarachchi, S., Gunasekera, S. A., and Balasooriya, I. (1983). Leaf spot diseases of water hyacinth in Sri Lanka. Journal of Aquatic Plant Management, 21(2): 62-65.

[13] Jafari, N. (2010). Ecological and socio-economic utilization of water hyacinth (Eichhornia crassipes Mart Solms). Journal of Applied Sciences and Environmental Management, 14(2). 
[14] Kotagama, S. W., and Bambaradeniya, C. N. B. (2006). An overview of the wetlands of Sri Lanka and their conservation significance. National Wetlands Directory of Sri Lanka, 7-16.

[15] Ganguly, A., Chatterjee, P. K., and Dey, A. (2012). Studies on ethanol production from water hyacinth-A review. Renewable and Sustainable Energy Reviews, 16(1):966-972.

[16] Vogel, Arthur J. (1978). Vogel's textbook of practical organic chemistry: including qualitative organic analysis. 547(6).

APPENDEX.

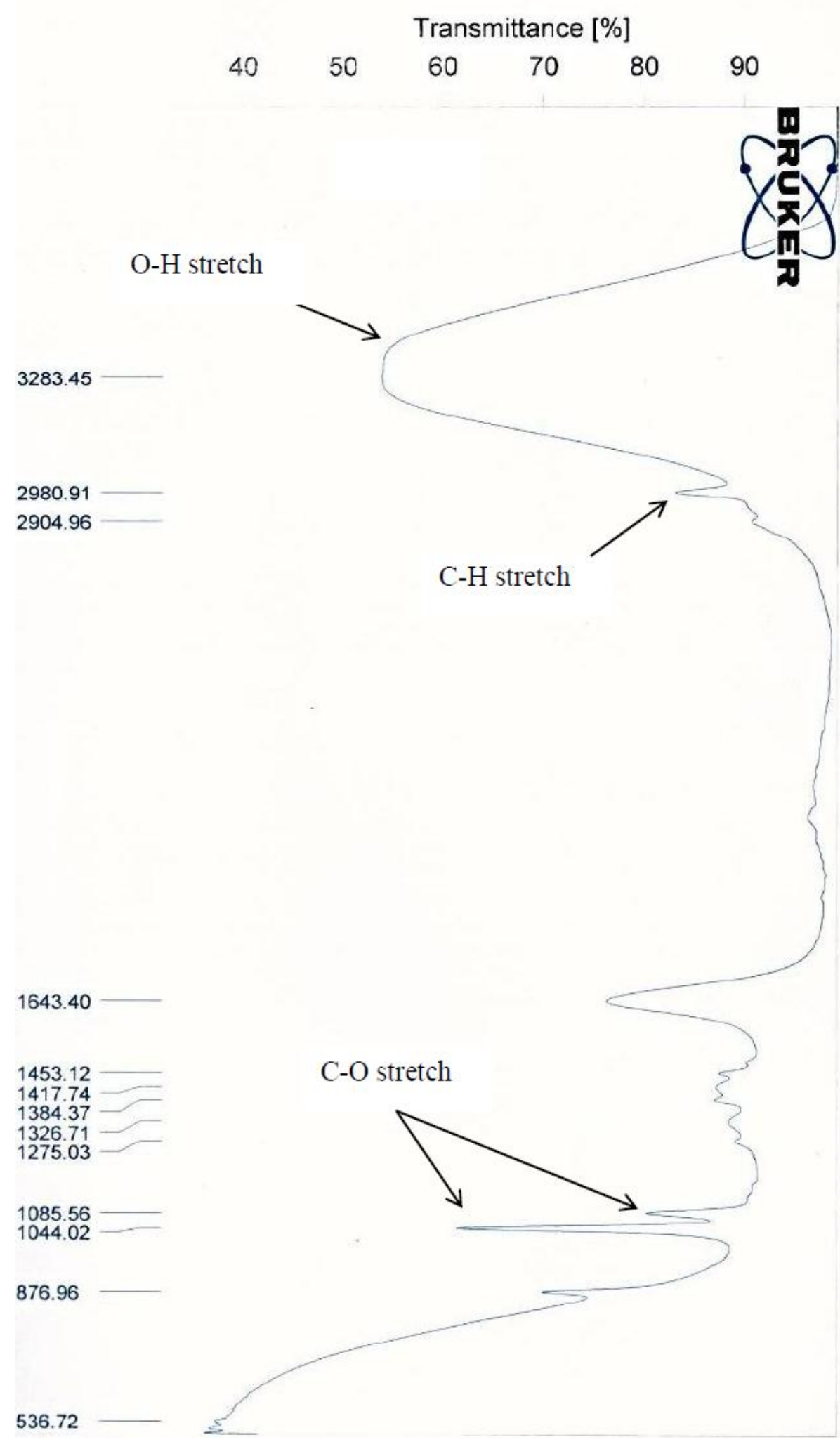

Figure2. The IR spectrum of distilled bio-ethanol from Rice Husk (RH) 


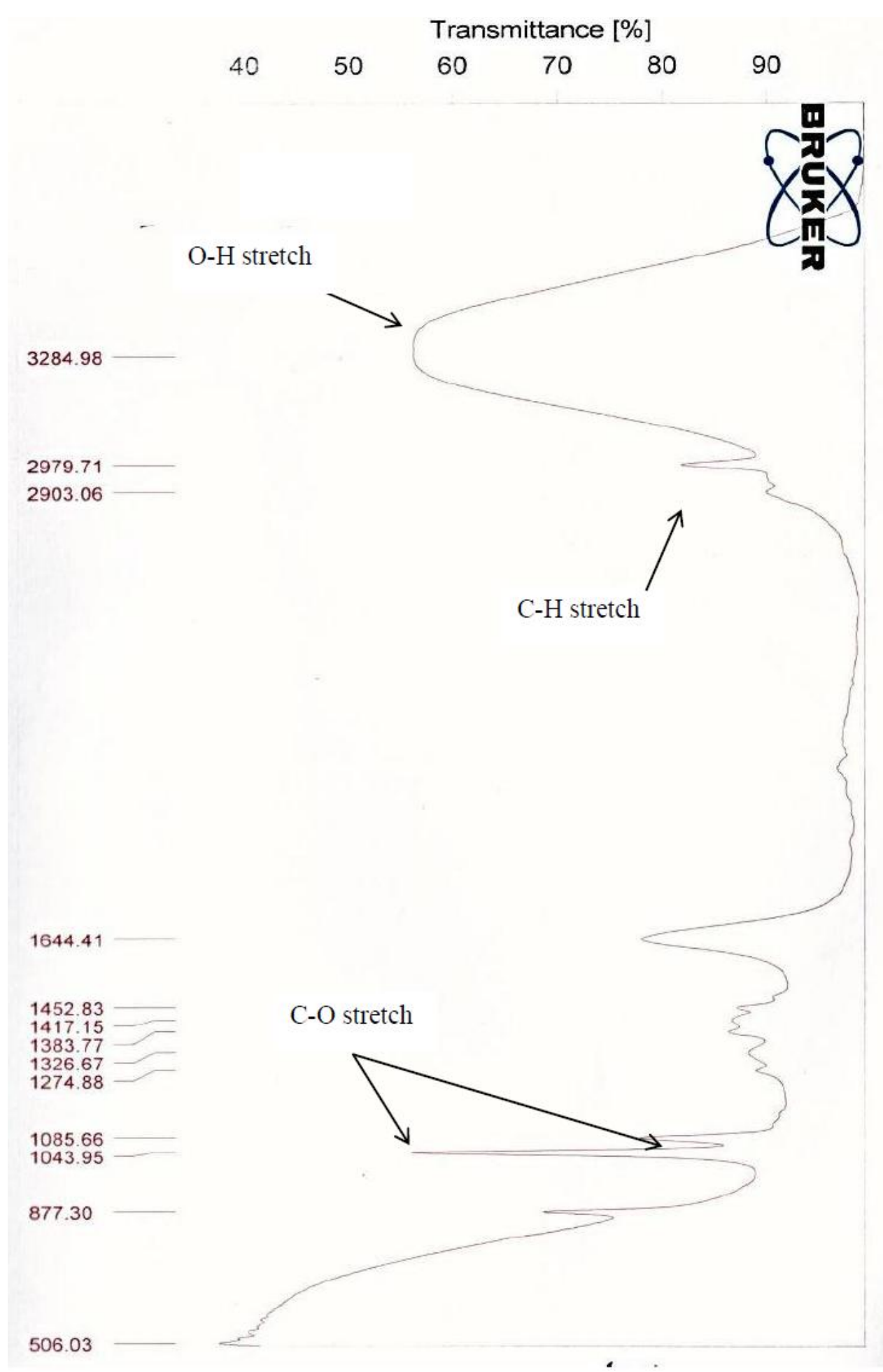

Figure3. The IR spectrum of distilled bio-ethanol from Water Hyacinth (WH)

Citation: S. Arasaretnam \& JMPW. Jayasundara "Utilization of Pretreated Lignocelluloses Materials for the Production of Bio-Diesel" International Journal of Advanced Research in Chemical Science (IJARCS), vol. 6, no. 1, pp. 7-12, 2019. http://dx.doi.org/10.20431/2349-0403.0602002

Copyright: (C) 2019 Authors. This is an open-access article distributed under the terms of the Creative Commons Attribution License, which permits unrestricted use, distribution, and reproduction in any medium, provided the original author and source are credited. 